\title{
IbM PELATIHAN PEMBUATAN MASKER KEPADA IBU IBU PKK DI KELURAHAN LIMBUNG KECAMATAN BAJENG KABUPATEN GOWA
}

\author{
Nurgahayu ${ }^{1}$, Sartika $^{2}$ \\ ${ }^{1,2}$ )Program Studi Kesehatan Masyarakat, Fakultas Kesehatan Masyarakat, Universitas Muslim Indonesia \\ email: Nurgahayu.nurgahayu@umi.ac.id, Sartika.suyuti@umi.ac.id
}

\begin{abstract}
Abstrak
Proses penularan penyakit menular saat ini semakin meningkat terutama penyakit menular melalui pernafasan. Jenis penyakit menular yang dapat ditularkan melalui udara dan pernafasan sangat banyak, salah satunya yang sedang dilanda oleh dunia saat ini adalah virus corona atau COVID-19. Meskipun belum ada data pasti kasus kejadian di Sulawesi Selatan, terutama di Kabupaten Gowa namun melihat proses penyebaran penyakit yang begitu cepat sehingga sangat diperlukan tindakan promotif dan preventif berupa pemberian edukasi terkait pencegahan penularan penyakit dan memberikan pelatihan pembuatan masker kepada ibu-ibu di Kelurahan Limbung Kecamatan Bajeng Kabupaten Gowa. Tujuan pengabdian ini meningkatkan pengetahuan ibu mengenai cara pembuatan masker yang sesuai untuk mencegah penularan penyakit dan meningkatkan pengetahuan ibu dalam upaya melakukan pencegahan penyakit menular melalui pernafasan. Pentingnya menumbuhkan minat ibu dalam upaya pencegahan penyakit dengan membuat masker sendiri yang sesuai standar yang dapat digunakan oleh semua anggota keluarga. Berdasarkan persentasi hasil ditemukan adanya peningkatan pengetahuan dan Terdapat peningkatan keterampilan membuat masker yang sesuai dengan standar kesehatan ibu-ibu PKK mengenai cara mencegah penularan penyakit melalui pernafasan. Pentingnya selalu melibatkan ibu-ibu dalam kegiatan pemberian edukasi dan pelatihan untuk lebih meningkatkan kesadaran masyarakat mengenai pencegahan penyakit melalui pernafasan terutama di saat Covid-19 saat ini.
\end{abstract}

Kata Kunci: Pelatihan, Masker, Pernafasan

\begin{abstract}
The current transmission of infectious disease is increasing primarily in communicable diseases through breathing. Highly airborne and respiratory infectious diseases, among the things that the world is currently engulfed in is the corona or covid-19 virus. Although there is no definite case in south sulawesi, especially in gowa county, it is seen that the rapid spread of disease requires a high degree of education in the prevention of disease and training for mothers in the limdistrict of gowa.The purpose of this devotion increased her knowledge of how appropriate masks were made to prevent the spread of disease and to increase her knowledge in efforts to prevent the spread of infectious disease through breathing. The importance of raising a mother's interest in the prevention of disease by making her own mask up to the standards that all in the family can use. According to the percentage found there has been increased knowledge and increased skill in making masks that match PKK mothers' health standards on how to prevent transmission of disease through breathing. The importance always includes mothers in educational and training activities to increase public awareness of respiratory prevention of disease especially at the current covid- 19 .
\end{abstract}

Keywords: Training, Masks, Breathing 


\section{PENDAHULUAN}

Proses penularan penyakit menular saat ini semakin meningkat terutama penyakit menular melalui pernafasan. Jenis penyakit menular yang dapat ditularkan melalui udara dan pernafasan sangat banyak, salah satunya yang sedang dilanda oleh dunia saat ini adalah virus corona atau Covid-19.

Berdasarkan data BBC News Pada 28 Februari 2020 menunjukkan virus corona telah menjangkiti 4.300 orang di seluruh dunia, menurut Organisasi Kesehatan Dunia (WHO). Namun, pakar penyakit menular Imperial College di London memperkirakan dua pertiga kasus Covid-19 yang berasal di China daratan masih belum terdeteksi di seluruh dunia. Ini dapat berarti "rantai penularan antar manusia belum terdeteksi" kata mereka. (BBC.News:2020)

Total kasus konfirmasi Covid-19 global per tanggal 8 Maret 2020 adalah 105.586 kasus, 80.859 kasus diantaranya dilaporkan dari Cina (tersebar di 34 wilayah termasuk Hong Kong SAR, Macau SAR, dan Taipei), dengan 83,7\% kasus konfirmasi dari Cina berasal dari Provinsi Hubei. Total kematian 3.584 kasus (CFR 3,4\%), 3.100 diantaranya dilaporkan dari Cina.

Kasus konfirmasi yang dilaporkan di 101 negara di luar negara Cina, sebanyak 24.727 kasus dengan 484 kematian di 16 negara (Amerika Serikat, Argentina, Australia, Belanda, Filipina, Irak, Iran, Italia, Jepang, Perancis, Republik Korea, Thailand, Spanyol, Swiss, San Marino, dan UK). (Kemkes:2020)

Sejak 30 Desember sampai 9 Maret 2020, terdapat 543 orang yang diperiksa dari 46 Rumah Sakit di 23 Provinsi dengan hasil pemeriksaan yaitu 487 orang negatif (188 orang Anak Buah Kapal kru kapal World Dream), 6 kasus konfirmasi positif Covid-19 dan 50 sampel masih dalam pemeriksaan. Kasus 1 merupakan kontak erat dari WN Jepang yang menjadi kasus konfirmasi ke-24 di Malaysia. Kasus ke-2, 3, 4, dan 5 merupakan kontak erat dari kasus 1. Dari lima kasus tersebut, 3 kasus dari Kota Depok, Jawa Barat dan 2 kasus dari DKI Jakarta. Kasus keenam merupakan Anak Buah Kapal kru Kapal Diamond Princess. Enam kasus konfirmasi tersebut dalam perawatan dan dalam kondisi membaik. Penularan penyakit tersebut bisa lewat air liur orang yang terinfeksi melalui bersin dan batuk dengan jarak tak lebih dari dua meter. Kontak jarak dekat bisa meningkatkan risiko seseorang terpapar wabah mematikan ini. Kontak jarak dekat yang bisa menularkan virus Corona dimaksud adalah berjabatan tangan, berciuman atau aktivitas lainnya yang melibatkan sentuhan langsung. Cara penularan virus Corona juga bisa terjadi jika bersentuhan dengan permukaan benda yang terpapar. Misalnya saja pegangan pintu, saklar, meja, tiang, atau benda-benda lainnya yang pernah disentuh penderita virus corona. Jika permukaan benda terpapar virus Corona disentuh lalu tangan secara tak sadar memegang hidung, mata, mulut atau organ lain yang memiliki selaput lendir, orang tersebut juga bisa tertular.

Direktur Pencegahan dan Pengendalian Penyakit sekaligus juru bicara penanganan Covid-19 Achmad Yurianto mengatakan data per tanggal 16 Maret 2020, jumlah kasus terkonfirmasi positif Covid-19 di Indonesia bertambah 17 orang. (kemenkes:2020). Meskipun belum ada data pasti kasus kejadian di Sulawesi Selatan, terutama di Kabupaten Gowa namun melihat proses penyebaran penyakit yang begitu cepat sehingga sangat diperlukan tindakan promotif dan preventif berupa pemberian edukasi terkait pencegahan penularan penyakit dan memberikan pelatihan pembuatan masker kepada ibu-ibu di Kelurahan Limbung Kecamatan Bajeng Kabupaten Gowa.

Permasalahan Mitra : (1) Masih rendahnya pengetahuan ibu-ibu dalam mencegah penularan penyakit melalui pernafasan. (2)Sulitnya memperoleh masker untuk mencegah penularan penyakit yang sesuai dengan standar untuk pencegahan penyakit menular melalui pernafasan. (3) Kelurahan Bajeng merupakan kelurahan yang terletak di jalan propinsi yang menjadi penghubung antar kabupaten, sehingga tempat ini dapat dijadikan sebagai tempat persinggahan orang-orang menuju ke daerah lain. Sehingga kemungkinan besar bisa terjadi penularan penyakit karena interaksi dengan orang lain. Tujuan dari kegiatan ini adalah untuk menumbuhkan minat dan pengetahuan ibu dalam upaya pencegahan penyakit dengan membuat masker sendiri yang sesuai standar yang dapat digunakan oleh semua anggota keluarga.

\section{METODE}

Metode pendekatan yang ditawarkan kepada mitra. Adapun uraian masing-masing metode pelaksanaan kegiatan yang ditawarkan sebagai solusi dari masalah yang ada pada ibu-ibu di Kelurahan Limbung sebagai berikut:Pelatihan yang bertujuan untuk menciptakan keterampilan pada ibu akan pembuatan masker berstandar untuk pencegahan penularan penyakit menular yang 
diakibatkan oleh virus. Kriteria peserta ibu-ibu PKK yang dianggap memiliki daya nalar untuk menerima intervensi berupa edukasi dan pelatihan yang dapat menumbuhkan minat dan pengetahuan mereka. Metode yang digunakan berupa: Diskusi dan tanya jawab, presentase, Pre-post test, simulasi/peragaan. Bahan dan alat yang digunakan: kain non anyaman tahan air, kain kasa, kain tenun, benang, jarum, mesin jahit tangan, setrika, Poster, ATK, LCD dan materi pelatihan

Program edukasi dan penyuluhan yang bertujuan untuk menambah pengetahuan ibu mengenai tata cara penggunaan masker dan langkah-langkah preventif yang dapat dilakukan untuk mencegah penyakit yang disebabkan oleh virus. Penyuluhan ini dilakukan oleh perwakilan dari Dosen FKM UMI dan dibantu oleh mahasiswa. Kriteria peserta adalah ibu ibu PKK yang dianggap memiliki daya nalar untuk menerima intervensi berupa edukasi dan penyuluhan yang dapat menumbuhkan minat dan pengetahuan mereka. Metode yang digunakan berupa: Diskusi dan tanya jawab, presentase, Pre-post test. Bahan dan alat yang digunakan: Poster, ATK, LCD dan materi penyuluhan.

\section{HASIL DAN PEMBAHASAN}

Berdasarkan hasil pre dan post test pada 25 ibu PKK yang terdiri dari 10 pertanyaan kuesioner, terdapat peningkatan pengetahuan mengenai cara pencegahan penyakit melalui pernafasan tersebut dapat diketahui berdasarkan tabel berikut:

\section{Hasil Pre dan Post Test Pelaksanaan Pengabdian Masyarakat Tentang Pencegahan Penyakit Menular Melalui Pernafasan di Kelurahan Limbung Kecamatan Bajeng Kabupaten Gowa}

\begin{tabular}{|l|l|l|l|l|l|l|}
\hline \multirow{2}{*}{$\begin{array}{l}\text { TINGKAT } \\
\text { PENGETAHUAN }\end{array}$} & \multicolumn{2}{l|}{ Cukup } & \multicolumn{2}{l|}{ Kurang } & \multicolumn{2}{l|}{ Total } \\
\cline { 2 - 7 } & $\mathrm{n}$ & $\%$ & $\mathrm{n}$ & $\%$ & $\mathrm{n}$ & $\%$ \\
\hline Pre Test & 8 & 32 & 17 & 68 & 25 & 100 \\
\hline Post Test & 2 & 8 & 23 & 92 & 25 & 100 \\
\hline
\end{tabular}

Sumber: Data Primer

Berdasarkan persentasi hasil yang dicapai, diketahui bahwa terdapat peningkatan pengetahuan Ibu-ibu PKK sebesar 92\%. Hal ini diakibatkan karena antusiasme ibu-ibu dalam menerima materi dan respon positif dari kegiatan yang kami lakukan.

Persiapan:Tahap persiapan kami mulai dengan menyiapkan bahan untuk pelatihan seperti menyewa mesin jahit portable, membeli perlengkapan jahit antara laian kain, kain kassa, benang, karet, tissue, Tahap persiapan pembuatan materi edukasi dalam bentuk power point, pemesanan poster, pembuatan spanduk, pembelian souvenir (masker dan plakat), Membuat surat izin pelaksanaan kegiatan,Melakukan sosialisasi yang dilakukan tanggal 10 Agustus 2020 di Kelurahan Limbung terkait dengan pelaksanaan kegiatan dan memberikan undangan kepada ibu-ibu PKK setempat.

a. Pelaksanaan

1. Membuka acara terlebih dahulu dalam hal ini dibuka oleh pihak pemerintah setempat

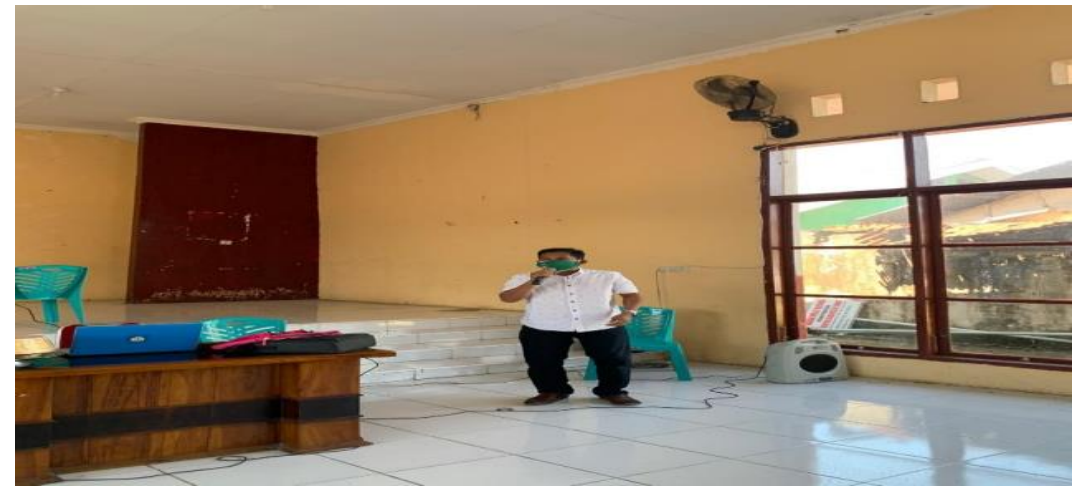

Gambar 1

Sambutan Kepala Kecamatan Bajeng Kabupaten Gowa 
2. Kami membagi kuesioner kepada para ibu-ibu untuk mengukur tingkat pengetahuan ibu terkait pencegahan penyakit menular melalui pernafasan sebelum diberi edukasi

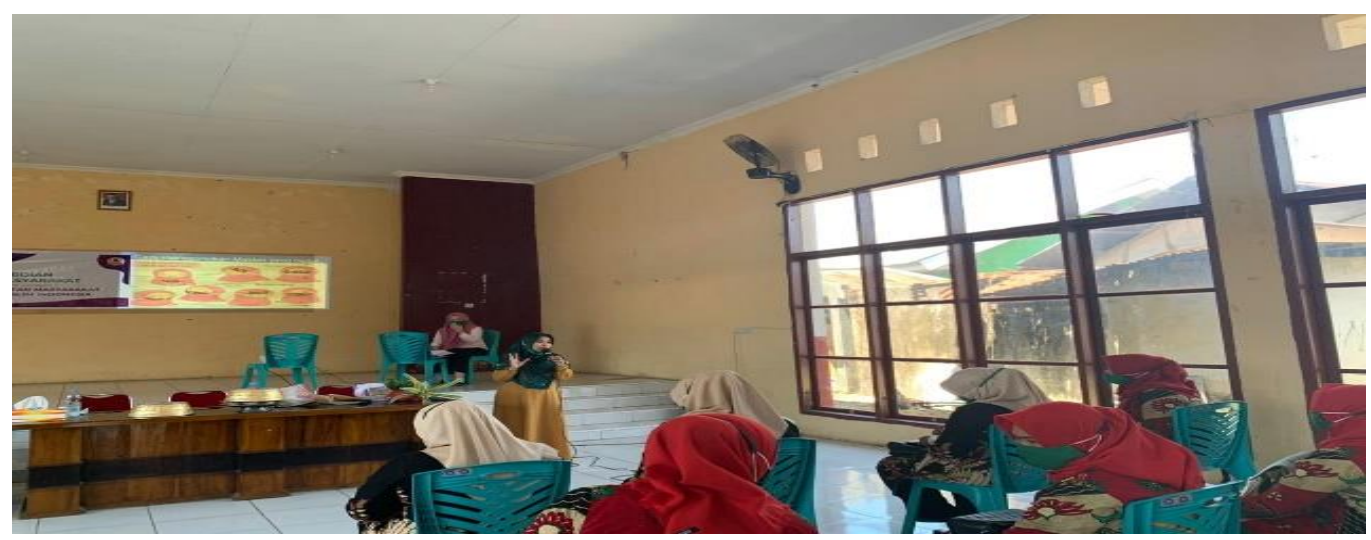

Gambar 2

Ibu-ibu PKK mengisi pre test

3. Memberikan edukasi pencegahan penyakit menular melalui pernafasan

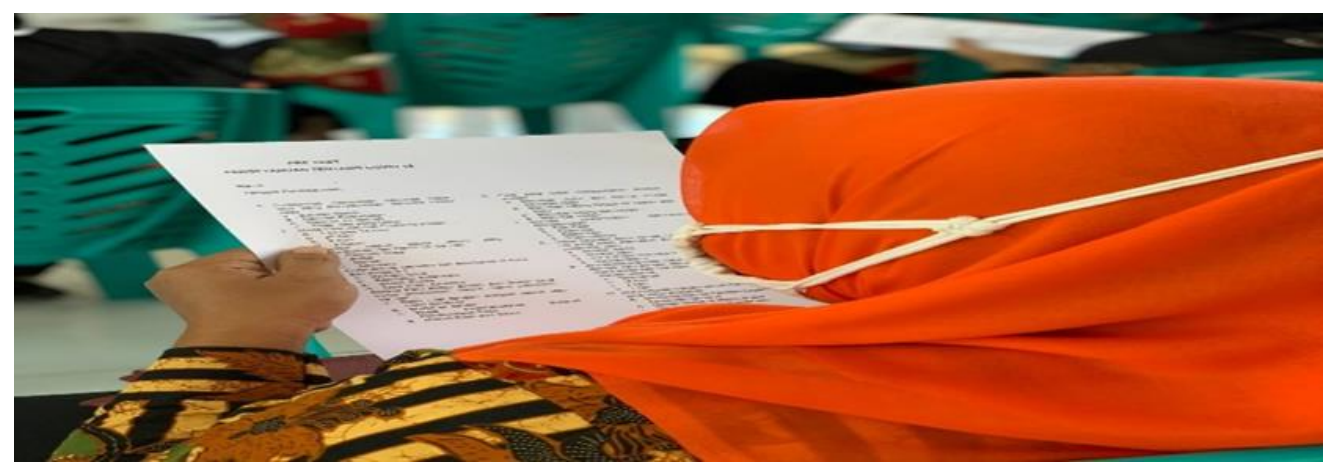

Gambar 3

Memberikan edukasi pencegahan penyakit menular melalui pernafasan

4. Memberikan pelatihan pembuatan masker

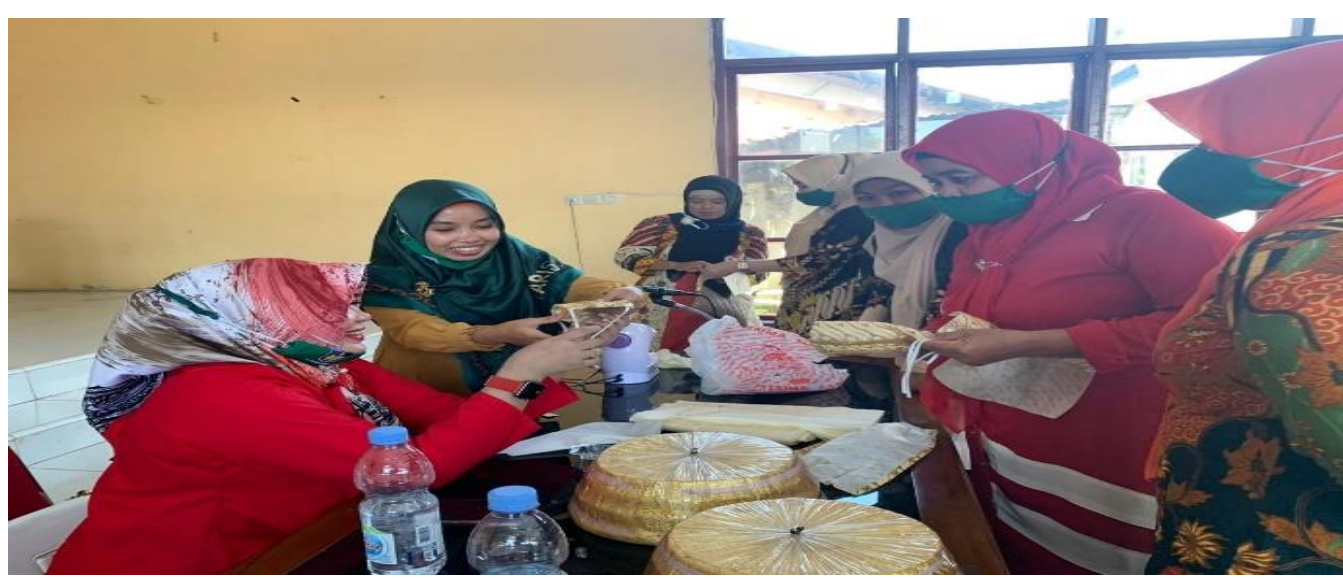

Gambar 4

Ibu-ibu PKK dilatih membuat masker 
5. Melakukan evaluasi tingkat pengetahuan ibu dengan melakukan post test terkait edukasi pencegahan penularan penyakit menular melalui pernafasan

\section{b. Penutupan}

1. Membagikan cendramata kepada pemerintah setempat dan souvenir kepada ibu-ibu PKK Kelurahan Limbung

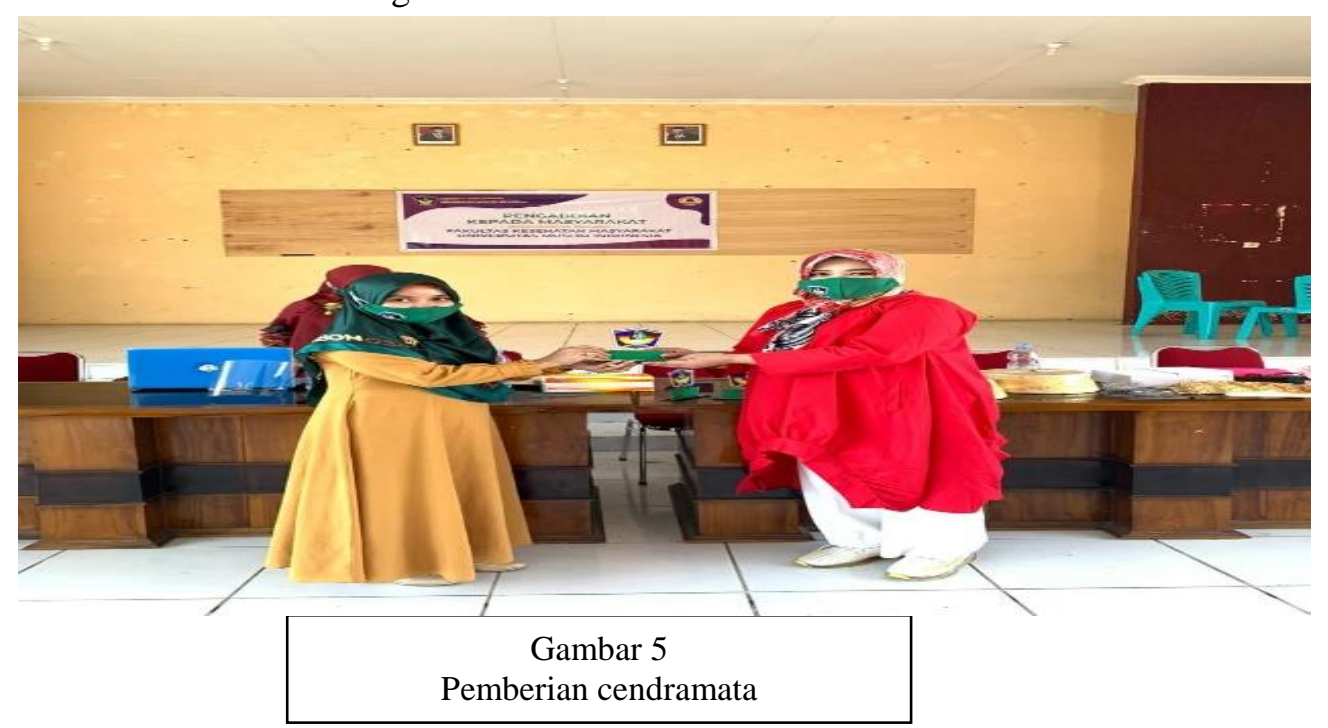

2. Memberikan poster penggunaan masker yang tepat

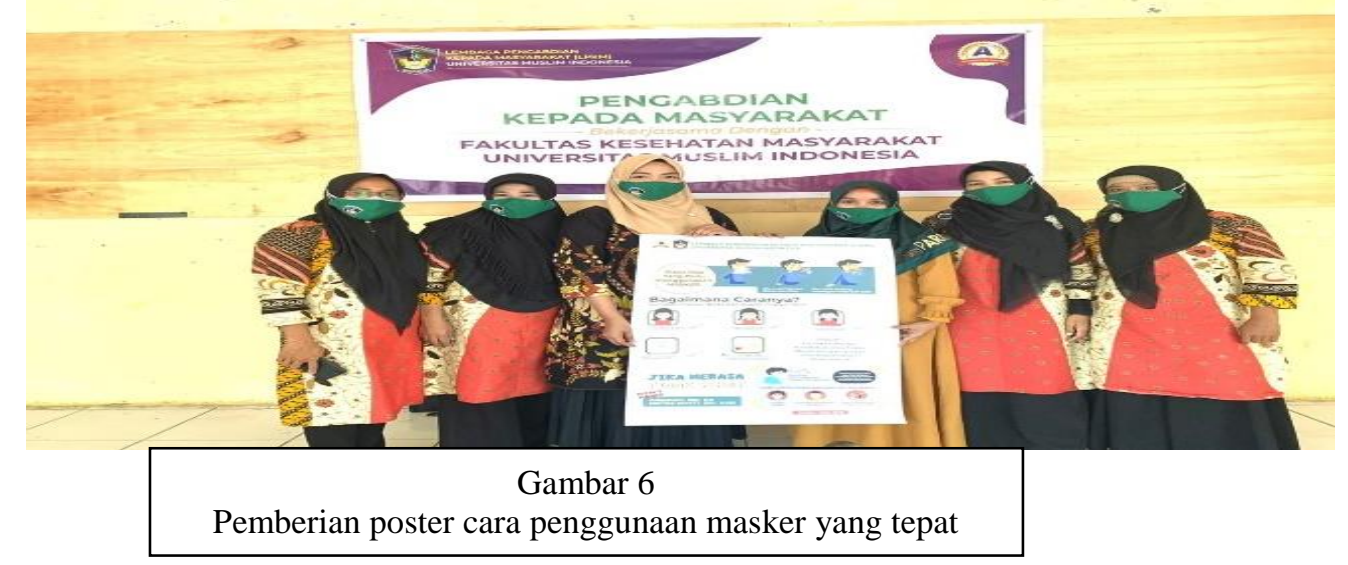

\section{Evaluasi Kegiatan}

Berdasarkan hasil kegiatan pengabdian masyarakat yang telah dilaksanakan, dapat dievaluasi bahwa meningkatnya pengetahuan ibu PKK diakibatkan karena pengetahuan mereka terkait pencegahan penyakit menular melalui pernafasan sudah cukup baik ditambah antusiasme mereka dalam mendengarkan materi edukasi menyebabkan semakin meningkanya pengetahuan ibu-ibu PKK. Selain dari hasil pre dan post tes yang telah dilakukan, evaluasi pada kegiatan ini juga dapat diketahui berdasarkan evaluasi secara kualitatif kepada mitra yang salah satunya dapat terlihat pada respon ibuibu ketika diberikan pelatihan dan edukasi yang membuat kegiatan ini semakin menarik.

\section{Permasalahan dan Hambatan}

Permasalahan yang muncul pada pengabdian masyarakat ini adalah terbatasnya jumlah ibuibu yang dilibatkan diakibatkan karena Pembatasan Sosial Berskala Besar (PSBB). Kegiatan ini dilakukan di Kantor Kecamatan dirangkaikan dgn kegiatan lain diakibatkan tidak tersedianya aula yang luas untuk menjaga jarak peserta di Kelurahan Limbung Kabupaten Gowa. 


\section{SIMPULAN}

Terdapatnya peningkatan pengetahuan mengenai cara mencegah penularan penyakit melalui pernafasan dan peningkatan keterampilan membuat masker yang sesuai dengan standar kesehatan.

\section{SARAN}

Pentingnya selalu melibatkan ibu-ibu dalam kegiatan pemberian edukasi dan pelatihan untuk lebih meningkatkan kesadaran masyarakat mengenai pencegahan penyakit melalui pernafasan terutama di saat Covid-19 saat ini

\section{UCAPAN TERIMA KASIH}

Terima Kasih kami ucapkan kepala Lembaga Pengabdian Masyarakat (LPkM) Universitas Muslim Indonesia yang telah membantu penganggaran dana dalam pelaksanaan kegiatan Pengabdian Masyarakat di Kelurahan Limbung Kecamatan Bajeng Kabupaten Gowa.

\section{DAFTAR PUSTAKA}

Kemenkes,2020. Dashboard Data Kasus Covid-19 di Indonesia. www.kemenkes.co.id

Kompas,2020. Ini jenis Bahan Yang direkomendasikan Untuk Membuat Masker Kain. www.kompas.com

Nurfitriyana Dewi, 2020. 3 Standar SNI terkait masker kain yang tepat.www.gooddoctor.co.id (diakses tanggal 1 Juni 2020)

Rafiqua Nurul, 2020. Wajib pakai masker saat keluar rumah, begini cara membuat masker kain yang efektif. www.sehatq.com (diakses tanggal 2 April 2020)

RH Lubis,2020. Penyakit corona ini jadi duri dalam perekonomian Indonesia

Susilo Adityo, 2020. Penyakit Coronavirus 2019, Jurnal Penyakit Dalam Indonesia, www.jurnalpenyakitdalam.ui.ac.id (diakses tanggal 2 Mei 2020) 